\title{
Impact of Basal-Like Breast Carcinoma Determination for a More Specific Therapy
}

\author{
Emad A. Rakha ${ }^{a} \quad$ Jorge S. Reis-Filho ${ }^{b}$ Ian O. Ellis ${ }^{a}$ \\ ${ }^{a}$ Department of Histopathology, Nottingham City Hospital NHS Trust, Nottingham University, Nottingham, and \\ ${ }^{b}$ The Breakthrough Breast Cancer Research Centre, Institute of Cancer Research, London, UK
}

\section{Key Words}

Breast cancer • Basal-like features · Therapeutic

implications

\begin{abstract}
Recent advances in high-throughput molecular technologies have made it possible to begin to tackle the molecular complexity of breast cancer and have contributed to the realisation that this biologic heterogeneity has implications for treatment. One of the major achievements of class discovery studies in breast cancer is the identification of a basal-like subtype that is characterised by absence of expression of hormone receptors and HER2 and has molecular features in common with basal/myoepithelial cells of the breast. Basal-like cancers have attracted attention as a poor prognostic class of tumours that lack the benefit of currently available targeted therapy. However, basal-like cancer as a distinct class of tumours, which share a specific molecular profile, are characterised by high proliferative activity and express specific markers, is a good candidate for development of specific targeted therapy. It is likely that in the near future, the ongoing research studies and clinical trials will provide an evidence-based approach to the best treatment strategy that can be applied to these tumours. In this review, we discuss the main features of basal-like tumours and recent evidence on the different available therapeutic approaches.

Copyright $\odot 2008$ S. Karger AG, Basel
\end{abstract}

\section{Introduction}

During the past three decades, the mortality rate of breast cancer in developed countries has declined $[1,2]$ as a result of a range of measures, including improvements in the local management of early breast cancer [3], and, most importantly, the introduction of adjuvant systemic treatments [4]. With more targeted treatments gradually emerging, further improvements in outcome of at least some subgroups of breast cancer will probably take place in the near future. In order to reduce the mortality from breast cancer further, there is a need to examine and characterize the molecular profiles of subclasses of tumours, which are of poor prognosis, to understand their biology, ensure adequate therapy and improve patients' outcome. There is also a need to develop additional forms of systemic treatment effective in those tumours failing to express known targets such as oestrogen receptor (ER), progesterone receptor (PR) or ERBB2 (HER2).

Recent advances in high-throughput molecular technologies have made it possible to begin to tackle the molecular complexity of breast cancer and have contributed to the realization that this biologic heterogeneity has implications for treatment. Molecular classification of cancer based on gene expression profiles was first reported in acute leukaemia [5], and then in malignant melanoma [6]. In the breast, molecular classification (class discovery) studies that have been pioneered by the Stanford

\section{KARGER}

Fax +41613061234

E-Mail karger@karger.ch

www.karger.com
(C) 2008 S. Karger AG, Basel

$1015-2008 / 08 / 0752-0095 \$ 24.50 / 0$

Accessible online at:

www.karger.com/pat
Prof. Ian O. Ellis

Molecular Medical Sciences, University of Nottingham

Department of Histopathology, Nottingham City Hospital NHS Trust

Hucknall Road, Nottingham, NG5 1PB (UK)

Tel. +44 115969 1169, Fax +44 115962 7768, E-Mail ian.ellis@nottingham.ac.uk 
group [7], in fact, have shaken the world of breast cancer research. These authors have proven the principle that breast cancer can be classified into molecularly distinct groups based upon gene expression profiles and their similarity to normal cell counterparts. Using a hierarchical clustering method and 'intrinsic gene set', they classified breast cancer into distinct molecular classes. These included ER-positive/luminal group and ER-negative group (the two main groups). The ER-negative group encompassed three subgroups of tumours, one expressing genes characteristic of basal/myoepithelial cells (basallike cancer), one overexpressing ERBB2 (HER2), and one with a gene expression profile similar to normal breast tissue, which consistently clusters together with normal breast samples and fibroadenomas.

Subsequent studies have been able to consistently identify most of the groups originally defined by Perou et al. [7], although some groups have been proven to be quite unstable. For instance, the subclassification of luminal tumours has ranged from a single group to up to three groups; 'normal breast-like' cancers have been shown to pertain to the ER-negative cluster in most but not all studies. Although subclusters of basal-like cancers have also been reported in a minority of studies [8], it has been uniformly shown that basal-like class cancer pertains to the ER-negative group. Using a similar principle, but reverse transcriptase-polymerase chain reaction (RT-PCR) and a panel of selected genes [9-11] or TMA with selected antibodies [12-16], rather than expression arrays, it has been possible to some extent to replicate this molecular classification. The importance of this molecular taxonomy is 2fold: (1) tumours pertaining to distinct molecular groups differ in their clinical behaviour, even though the classification system was not developed to predict outcomes, and (2) transcriptomic analysis has given some leads on genes that may drive each molecular subgroup. These findings have not only expanded our knowledge on the molecular pathways involved in the development of specific molecular subtypes of breast cancer, but also provided novel and rather interesting putative therapeutic targets (see below).

Although the existence of a group of breast cancers characterized by the expression of markers characteristic of basal/myoepithelial cells [i.e. high molecular weight (basal) cytokeratins (CK)] and poor prognosis was actually described two decades ago [17, 18], this subgroup has only been brought to the forefront of breast cancer research after their 'rediscovery' by gene expression profiling studies. These tumours that are currently known as basal-like cancer represent $16 \%$ to up to $37 \%$ of all breast cancer cases $[8,19,20]$.

\section{Molecular Features of Basal-Like Breast Cancer}

These tumours express genes previously identified to be characteristic of basal/myoepithelial cells such as CK5 and 17, integrin 4, and laminin, c-KIT, $\alpha_{6}$ integrin, metallothionein $1 \mathrm{X}$, fatty acid binding protein 7 , P-cadherin, EGFR, caveolins 1 and 2, and nuclear factor-kB (NF-kB) [7, 21-24]. Other genes included (1) those that activate signalling pathways, which are commonly deregulated in cancer, such as MEK, ERK and PI3 kinases, AKT kinases, p38, MRAS, CDCA7 and NF-kB; (2) proliferation and mitotic checkpoint control genes and cell growth-related genes such as cyclin E1, BUB1, MYBL2, TTK, topoisomerase II $\alpha$, MCM2, MAD2L1, STK6, CDC2, CDCA3, CDCA5 and PCNA, and (3) tyrosine kinase receptors and genes involved in signal transduction and transcription factors (EGFR, caveolin 1 and 2, hepatocyte growth factor, pleiotrophin, c-fos, and c-jun). They also express other genes such as alphaB-crystallin and Hsp27 and TGF 32 . Basal-like tumours usually lack expression of hormone receptors (ER and PR), transcription factors, oncogenes such as GATA transcription factors (GATA3), basic transcription factor 3, FOXC1, FOXA1, TFF3, X-box binding protein 1, RAB, HER2, GRB7, GTPase binding effector protein 1, fibronectin-1 and mucin-1 [7, 8, 21, 23-26].

Basal-like breast cancers usually show $\mathrm{p} 53$ protein nuclear expression and TP53 gene mutations are found in $>85 \%$ of these tumours [27-30]. In addition, it is now recognized that tumours from patients carrying $B R C A 1 \mathrm{mu}-$ tations fell within the basal-like subgroup [27, 31-34], suggesting similar carcinogenic pathways or causes of these two subtypes [27]. There are also several lines of evidence to suggest a link between basal-like breast cancer and a dysfunctional $B R C A 1$ pathway $[32,35]$. The majority of $B R C A 1$-associated tumours are 'triple-negative', express basal CKs, in addition to other markers commonly seen in basal-like tumours such as p53, P-cadherin and EGFR [27, 29, 33, 36-40]. As with basal-like tumours, cytogenetic abnormalities are common in BRCA1 mutation-related breast cancers $[41,42]$ and a set of characteristic cytogenetic changes in BRCA1-associated breast cancers $[41,43]$ has been described in sporadic basal-like cancers [44-46]. In addition, there is some evidence to suggest that both sporadic basal-like and BRCA1 breast tumours have frequent loss of X-chromosome inactivation $[47,48]$. Although it is not clear whether in humans $B R C A 1$ inactivation is the cause or a consequence of a basal-like phenotype, two hypotheses have been advanced for the similarities between basal-like cancers 
and tumours arising in BRCA1 mutation carriers: first, the precursors of basal-like cancers (likely to be basal-like ductal carcinoma in situ) [49-51] and invasive basal-like breast carcinomas may be more tolerant to loss of BRCA1 function than those of other breast cancer subtypes, possibly due to the phenotype of the cell of the initiating event or the concurrent inactivation of other tumour suppressor genes, such as TP53. Alternatively, BRCA1 may be involved in the differentiation of breast epithelial cells and, therefore, BRCA1 inactivation would lead to tumours with a stem cell-like phenotype $[52,53]$. Furthermore, given the reported action of $B R C A 1$ in regulating the ER pathway [54], BRCA1 dysfunction may actively lead to the development of tumours with a basal-like phenotype [55]. Although the above hypotheses are sensible, there is no direct evidence to support one and refute the others. However, this is a field that is rapidly evolving and evidence-based answers may emerge in the near future. From a clinical standpoint, the relationship between sporadic basal-like tumours and tumours arising in $B R C A 1$ mutation carriers has provided an opportunity to narrow down which gene should be sequenced in cases of familial breast cancer compatible with either $B R C A 1$ or $B R C A 2$ mutations: tumours of high histological grade, with pushing borders, brisk lymphocytic infiltrate, lacking ER and expressing basal keratins are highly likely to be associated with a germline mutation in $B R C A 1$ rather than BRCA2 [32, 34, 35].

\section{Clinical Features of Basal-Like Breast Cancer}

Before discussing the clinical features and prognostic significance of basal-like cancer, the importance of the definition of basal-like cancer, its impact on the clinicopathological features of tumours defined as such and, more importantly, their response to therapy need to be emphasized. To date there is no internationally accepted definition for basal-like cancers. Although the majority of basal-like tumours are characterized by a constellation of histopathological features similar to those observed in $B R C A 1$ mutation carriers [56, 57], there is no specific hallmark histological feature that can identify those tumours reliably on routine practice. Therefore, the only realistic, potentially objective, and convenient method to identify these basal-like carcinomas in clinical specimens would be through the positive detection of certain markers. Several immunohistochemical (IHC) surrogates have been proposed for the routine identification of basal-like breast tumours. The first definition was proposed by
Nielsen et al. [58] who defined basal-like cancers as those negative for ER and HER2 and positive for CK5/6 and/or EGFR. These criteria for definition of basal-like tumours were adopted by many other authors [59-64]. Others have included PR in the definition [ER, PR, HER2-negative ('triple-negative'), and CK5/6 and/or EGFR-positive] [60]. However, many other authors including our group have used basal CK alone to define basal-like cancer without restriction to the triple-negative tumours $[29,39$, 65-70]. Importantly, none of the IHC definitions to date has been shown to accurately identify all basal-like breast cancers; however, most of these IHC surrogates identify groups of tumours whose characteristics are remarkably similar to those identified by microarray-based expression profiling analysis.

Basal-like phenotype strongly correlates with the lack of ER and PR and HER2 expression (i.e., triple-negative phenotype) [71, 72]. Triple-negative tumours are undeniably one of the most relevant subgroups of breast cancer from a medical oncologist's perspective, given the lack of targeted therapies for this group and their aggressive clinical behaviour. However, triple-negative and basallike are not exactly the same entity and equating them may be misleading. In two expression profiling studies where the expression of hormone receptors was analyzed in tumours classified according to the 'intrinsic gene list', ER expression was seen in 5-45\% of basal-like cancers. In addition, Rouzier et al. [72] have demonstrated that approximately $15 \%$ of basal-like cancers also express HER2. On the other hand, triple-negative tumours are not necessarily basal-like. In fact, it has been demonstrated that a significant proportion of 'normal breast-like cancers' as defined by expression arrays lack hormone receptors and HER2 [73]. Although the latter group is still poorly characterized, they are reported to have a prognosis which seems to be better than that of basal-like cancers $[26,71,74]$ and do not seem to respond to neoadjuvant chemotherapy $[72,75]$. In fact, in one study, $45 \%$ of patients with basal-like cancer showed pathological complete response following anthracycline plus taxane neoadjuvant chemotherapy, whereas none of the normal breast-like cancers did so [72]. We [76] and others [74] have demonstrated that the expression of basal markers (i.e. basal CKs and EGFR) identifies a clinically significant subgroup within the triple-negative group. On the other hand, expression of basal CKs and/or EGFR [74, 76, 77], regardless of the expression of ER or PR status, identifies a subgroup of cancers that display a poor prognosis, even at 10 years. Furthermore, basal-like cancers, as shown in most studies, are not, completely, receptor poor 
and express multiple receptor tyrosine kinases including HER1, HER3, HER4, and c-kit [16, 56], and hormone (androgen) receptors [28]. Thus, correlative studies where triple-negative phenotype is used as a definition for basal-like cancers are likely to include in the study group a mixture of basal-like and non-basal-like tumours. This inevitably leads to a great deal of heterogeneity in terms of histology and clinical behaviour. Furthermore, a small but significant proportion of basal-like cancers (as defined by expression arrays) would be excluded from the study group if a triple-negative definition was used. Similarly using singe basal markers (e.g. a single basal CK) to define basal-like is likely to identify only a proportion of basal-like tumours. This group identified by single markers may recapitulate some, but not all features of the whole group of basal-like cancers, which may lead to inaccurate conclusions on the biology and clinical behaviour of these cancers.

By defining basal-like cancers either in terms of mRNA expression profile or expression of basal phenotype biomarkers, studies are consistent in their morphological description of this class of breast cancer. The majority of these tumours are ductal carcinomas of no special type, but occasionally either tubular mixed [28], metaplastic [78], or medullary cancers [79]. They have common features including younger patients' age, high histological tumour grade, marked cellular pleomorphism, high nuclear-cytoplasmic ratio, lack of tubule formation, high mitotic index, frequent apoptotic cells, scant stromal content, a pushing border of invasion, central geographic or comedo-type necrosis. They are also characterized by the presence of metaplastic elements such as spindle cells and squamous cell metaplasia, presence of a central scar, glomeruloid microvascular proliferation and a brisk inflammatory infiltrate $[28-30,46,57,66,73,80,81]$. In addition, some reports have suggested that basal-like tumours may achieve extraordinarily rapid clinical growth rates [82]. The high proliferative activity of basal-like tumours may probably explain why these tumours are overrepresented amongst the so-called interval breast cancers (e.g., cancers arising between annual mammograms) [83].

Despite differences in the definition and prevalence of basal-like tumours in various studies, the poor outcome of patients with basal-like tumours has been remarkably reproducible across many different patient populations $[8,26,27,29,60,66,69,70]$. Basal-like cancer is associated with an aggressive clinical history, development of distant metastasis, shorter survival and a relatively high mortality rate $[27-29,60,66,67,84]$. In addition, basallike tumours show a specific pattern of distant metastasis with an increased propensity for visceral metastases to brain and lung, sites known to be associated with a poorer prognosis $[67,85,86]$ and which less likely metastasize to bone and liver and to axillary lymph nodes $[66,67,80$, $87,88]$. These findings suggest that basal-like tumours might also possess a distinct mechanism of metastatic spread.

\section{Therapeutic Implications of Basal-Like Tumours}

The increased recognition of the basal-like molecular subgroup, in fact, could be considered as one of the most important achievement of gene expression microarrays in breast cancer. Since their rediscovery by microarray analysis, basal-like tumours have received unprecedented levels of attention in the literature. Their importance mainly stems from the following: (1) being a group of tumours that share a specific molecular profile with similarities to basal/myoepithelial cells of the breast and the arguably stem/progenitor cells [89], and more importantly being a good candidate for development of specific targeted therapy; (2) basal-like cancer often has a 'triple-negative' phenotype; as a result, the majority of these tumours cannot be effectively managed with existing targeted treatments (trastuzumab and hormonal treatments); (3) the reported poor prognosis of basal-like tumours with shorter survival and unique pattern of metastasis, and (4) finally, basal-like cancer can be considered the most significant class of breast cancer identified by gene expression microarrays since other classes have either already been known for a long time (HER2-positive tumours and ER-positive tumours/luminal class) with currently available targeted therapy, or poorly defined with classes that lack reproducibility of their molecular or prognostic features (normal breast-like class and luminal C classes).

Despite the aggressive behaviour of basal-like cancer, current routine diagnostic practice does not specifically recognize these tumours and their management is still the same as that of other grade- and stage-matched breast cancers. This is mainly because the genes that are responsible for their aggressive phenotype are not yet well understood. However, there are different lines of treatment of basal-like cancers that are currently under investigation: local treatment and systemic treatment which includes chemotherapy and targeted therapy.

\section{Local Treatment}

It has been reported that basal-like tumours either defined by the triple-negative phenotype $[76,90]$ or by bas- 
al CK expression [28] are not associated with increased risk for locoregional relapse after conservative surgery [91]. In fact, these findings together with the frequent pushing well-defined border of invasion in these tumours and absence of association with vascular invasion or lymph node involvement $[29,56,67,70,73,92]$ do not appear to justify a more radical approach to local or axillary surgery. The potentially aggressive behaviour of these tumours may be better approached by use of systemic therapy (see below).

\section{Response to Chemotherapy}

There are several features inherent to basal-like cancers that have consistently been shown in previous studies to be associated with clinical and pathological responsiveness to neoadjuvant chemotherapy in general such as ER negativity [93], and a high proliferative activity [94]. In fact, most previous studies of basal-like cancer were either retrospective, or failed to include a control group, or were not sufficiently powered. However, the response of basal-like tumours to chemotherapy is currently under investigation. It has been reported that basal-like tumours as defined by gene expression profiling may have a better response to neoadjuvant chemotherapy (as defined by pathological complete response) than those that exhibit a non-basal-like profile, either to Adriamycin and cyclophosphamide [95] or to paclitaxel, doxorubicin, 5fluorouracil and cyclophosphamide [72]. Paradoxically, in one of these studies, despite the significantly higher prevalence of pathological complete response in the basal-like group, patients with these tumours still displayed the worst outcome [95]. Basal-like cancers have also been shown to have a significant benefit from high-dose chemotherapy [81].

It could be argued that the high prevalence of TP53 mutations in basal-like cancers would define their pattern of response to chemotherapy. For instance, there are data to suggest that basal-like cancers display a rather poor prognosis when treated with adjuvant anthracycline-based chemotherapy [91]. This could be explained by the reported resistance of TP53-mutated breast cancers to anthracycline chemotherapy [96]. However, results on the role of TP53 mutations in resistance or sensitivity to taxanes are less clear [97]; in one study [98] a response was seen in the presence of a p53 deficiency, but a normal level of p53 expression was associated with resistance. Moreover, it has been reported that that tumours with BRCA1 deficiency may be highly sensitive to anthracycline-based or platinum salt-based chemotherapy [99]. These studies suggest that basal-like tumours, like
BRCA1-associated tumours [100], might be sensitive to certain chemotherapeutic agents, and that the poor prognosis of these tumours might be improved by chemotherapy.

Although it has been reported that basal-like tumours may have a better response to conventional chemotherapy $[81,95]$, basal-like phenotype does not seem to be an independent predictor of chemotherapy response after accounting for the contribution of high-grade, high-proliferation rates and hormone receptor-negative status of these tumours [72] and a recent study has reported a low response rate of basal-like tumours to neoadjuvant therapy with docetaxel, Adriamycin, and cyclophosphamide [75]. Whether more aggressive treatment procedures can improve the outcome for these patients and which of the available regimens would provide the greatest benefit remain to be determined.

\section{Targeted Therapy}

The expression of several potential therapeutic targets has been identified in basal-like tumours including surface receptors, such as epidermal growth factor receptor [EGFR (HER1), HER3 and HER4] [28, 58, 65] and c-KIT, tyrosine kinase components of the mitogen-activated protein (MAP)-kinase pathway, and tyrosine kinase components of the protein kinase $\mathrm{B}$ (Akt) pathway. The fundamental biological similarities between $B R C A 1$ and basal-like tumours suggest that strategies targeting the dysfunctional BRCA1 pathway characteristic of basal-like tumours may be effective [101]. There is increasing evidence that the DNA repair defects characteristic of $B R C A 1$-related cancers, especially defective homologous recombination, confer sensitivity to certain systemic agents, such as platinum salt-based chemotherapy and poly(ADP-ribose) polymerase (PARP) inhibitors [101104].

Proliferative signals in the form of cytokines, growth factors or hormones activate receptors, which trigger intracellular signalling cascades that ultimately bring about changes in gene expression. These consist of protein kinases which phosphorylate target proteins, thereby controlling their enzyme activity, interactions with other molecules, cellular location, and resistance to degradation. Many components of these proliferative pathways are overexpressed, amplified and/or mutated in cancer cells, and, therefore, represent potential targets [105]. Many components of these pathways are currently being assessed as potential therapeutic targets in the treatment of breast cancer. The growth factor receptor, c-KIT, which is expressed in a high proportion of basal-like cancers 
$[58,106,107]$, has been successfully targeted in other tumour types by imatinib mesylate or other type III tyrosine kinase receptor inhibitors. Although these findings should be interpreted with caution as some reports demonstrated that the most powerful predictor of response to imatinib, activating KIT gene mutations, are not found in c-KIT-positive breast cancers [107]. Dasatinib, a src inhibitor, has been shown in preclinical models to be most effective in 'triple-negative'/basal-like breast cancers $[108,109]$. Although the actual target of this inhibitor in basal-like cancers remains to be determined and no evidence based on clinical experience has been gathered to date, this tailored therapy agent may prove useful for future management of patients with basal-like cancers [109]. EGFR is expressed in $>60 \%[58,65]$ and amplified in a subset of basal-like tumours [110]. EGFR signalling has been inhibited in other cancer types with some clinical success, either by using EGFR directed antibodies or the inhibitors of receptor phosphorylation [111, 112]. Clinical trials are underway to investigate the efficacy of anti-EGFR (cetuximab either alone or combined with chemotherapy) in basal-like cancer.

In addition, there is also an interest in the application of multikinase inhibitors in breast cancer, such as lapatinib, which inhibits activity of both the EGFR and HER2 receptor kinases, and pertuzumab that blocks the homodimerization and heterodimerization of HER2. Preliminary data from a phase 1 study of lapatinib in metastatic breast cancer showed activity in many HER-positive breast cancer cases, but activity in HER2-negative breast cancers (including basal-like) is unclear [113].

\section{Conclusion}

Basal-like breast cancer is a distinct group of aggressive tumours that show common but heterogeneous morphological, genetic and immunophenotypic features. Identification of these tumours in clinical practice may be important given the great potential of emerging therapeutic targets in these tumours. Basal-like tumours may require a more aggressive intervention and should raise the suspicion of a $B R C A 1$ germline mutation, particularly if they are hormone receptor negative $[32,34]$. Current evidence does not justify a more radical approach to local or axillary surgery. The potentially aggressive behaviour of these tumours may be better approached by use of systemic therapy. Basal-like tumours might be sensitive to certain chemotherapeutic agents, and the poor prognosis of these tumours might be improved by chemotherapy. These tumours may have a better response to neoadjuvant chemotherapy and may benefit from high-dose chemotherapy. Although no targeted therapy for basal-like cancer is currently available, several potential therapeutic targets have been identified in these tumours including EGFR, HER3 and HER4, c-KIT, tyrosine kinase components of the mitogen-activated protein (MAP)-kinase pathway, and tyrosine kinase components of the protein kinase B (Akt) pathway. Whether more aggressive treatment procedures can improve the outcome for these patients and which of the available regimens would provide the greatest benefit remain to be determined.

\section{References}

1 Peto R, Boreham J, Clarke M, Davies C, Beral V: UK and USA breast cancer deaths down $25 \%$ in year 2000 at ages $20-69$ years. Lancet 2000;355:1822.

-2 Kamangar F, Dores GM, Anderson WF: Patterns of cancer incidence, mortality, and prevalence across five continents: defining priorities to reduce cancer disparities in different geographic regions of the world. J Clin Oncol 2006;24:2137-2150.

-3 Overgaard M, Jensen MB, Overgaard J, Hansen PS, Rose C, Andersson M, et al: Postoperative radiotherapy in high-risk postmenopausal breast-cancer patients given adjuvant tamoxifen: Danish Breast Cancer Cooperative Group DBCG 82c randomised trial. Lancet 1999;353:1641-1648.
-4 Early Breast Cancer Trialists' Collaborative Group (EBCTCG): Effects of chemotherapy and hormonal therapy for early breast cancer on recurrence and 15-year survival: an overview of the randomised trials. Lancet 2005; 365:1687-1717.

$\checkmark 5$ Golub TR, Slonim DK, Tamayo P, Huard C, Gaasenbeek M, Mesirov JP, et al: Molecular classification of cancer: class discovery and class prediction by gene expression monitoring. Science 1999;286:531-537.

6 Bittner M, Meltzer P, Chen Y, Jiang Y, Seftor E, Hendrix M, et al: Molecular classification of cutaneous malignant melanoma by gene expression profiling. Nature 2000;406:536540.
7 Perou CM, Sorlie T, Eisen MB, van de Rijn M, Jeffrey SS, Rees CA, et al: Molecular portraits of human breast tumours. Nature 2000;406: 747-752.

-8 Sotiriou C, Neo SY, McShane LM, Korn EL, Long PM, Jazaeri A, et al: Breast cancer classification and prognosis based on gene expression profiles from a population-based study. Proc Natl Acad Sci USA 2003;100: 10393-10398.

$\checkmark 9$ Mullins M, Perreard L, Quackenbush JF, Gauthier N, Bayer S, Ellis M, et al: Agreement in breast cancer classification between microarray and quantitative reverse transcription PCR from fresh-frozen and formalin-fixed, paraffin-embedded tissues. Clin Chem 2007;53:1273-1279. 
10 Chanrion M, Fontaine H, Rodriguez C, Negre V, Bibeau F, Theillet $\mathrm{C}$, et al: A new molecular breast cancer subclass defined from a large scale real-time quantitative RT-PCR study. BMC Cancer 2007;7:39.

- 11 Perreard L, Fan C, Quackenbush JF, Mullins M, Gauthier NP, Nelson E, et al: Classification and risk stratification of invasive breast carcinomas using a real-time quantitative RT-PCR assay. Breast Cancer Res 2006;8: R23.

-12 Abd El-Rehim DM, Ball G, Pinder SE, Rakha E, Paish C, Robertson JF, et al: High-throughput protein expression analysis using tissue microarray technology of a large well-characterised series identifies biologically distinct classes of breast cancer confirming recent cDNA expression analyses. Int J Cancer 2005;116:340-350.

13 Makretsov NA, Huntsman DG, Nielsen TO, Yorida E, Peacock M, Cheang MC, et al: Hierarchical clustering analysis of tissue microarray immunostaining data identifies prognostically significant groups of breast carcinoma. Clin Cancer Res 2004;10:61436151.

-14 Jacquemier J, Ginestier C, Rougemont J, Bardou VJ, Charafe-Jauffret E, Geneix J, et al: Protein expression profiling identifies subclasses of breast cancer and predicts prognosis. Cancer Res 2005;65:767-779.

15 Ambrogi F, Biganzoli E, Querzoli P, Ferretti S, Boracchi P, Alberti S, et al: Molecular subtyping of breast cancer from traditional tumor marker profiles using parallel clustering methods. Clin Cancer Res 2006;12:781-790.

16 Dolled-Filhart M, Ryden L, Cregger M, Jirstrom K, Harigopal M, Camp RL, et al: Classification of breast cancer using genetic algorithms and tissue microarrays. Clin Cancer Res 2006;12:6459-6468.

17 Santini D, Ceccarelli C, Taffurelli M, Pileri S, Marrano D: Differentiation pathways in primary invasive breast carcinoma as suggested by intermediate filament and biopathological marker expression. J Pathol 1996;179:386-391.

$\checkmark 18$ Dairkee SH, Ljung BM, Smith H, Hackett A: Immunolocalization of a human basal epithelium specific keratin in benign and malignant breast disease. Breast Cancer Res Treat 1987;10:11-20.

19 van de Vijver MJ, He YD, van't Veer LJ, Dai H, Hart AA, Voskuil DW, et al: A gene-expression signature as a predictor of survival in breast cancer. N Engl J Med 2002;347 1999-2009.

20 West M, Blanchette C, Dressman H, Huang E, Ishida S, Spang R, et al: Predicting the clinical status of human breast cancer by using gene expression profiles. Proc Natl Acad Sci USA 2001;98:11462-11467.
21 Savage K, Lambros MB, Robertson D, Jones $\mathrm{RL}$, Jones C, Mackay A, et al: Caveolin 1 is overexpressed and amplified in a subset of basal-like and metaplastic breast carcinomas: a morphologic, ultrastructural, immunohistochemical, and in situ hybridization analysis. Clin Cancer Res 2007;13:90-101.

22 Vogelstein B, Kinzler KW: Cancer genes and the pathways they control. Nat Med 2004;10: 789-799.

23 Yehiely F, Moyano JV, Evans JR, Nielsen TO, Cryns VL: Deconstructing the molecular portrait of basal-like breast cancer. Trends Mol Med 2006;12:537-544.

$24 \mathrm{Hu}$ Z, Fan C, Oh DS, Marron JS, He X, Qaqish BF, et al: The molecular portraits of breast tumors are conserved across microarray platforms. BMC Genomics 2006;7:96.

25 Molkentin JD: The zinc finger-containing transcription factors GATA-4, -5 , and -6 . Ubiquitously expressed regulators of tissuespecific gene expression. J Biol Chem 2000; 275:38949-38952.

26 Sorlie T, Perou CM, Tibshirani R, Aas T, Geisler S, Johnsen H, et al: Gene expression patterns of breast carcinomas distinguish tumor subclasses with clinical implications. Proc Natl Acad Sci USA 2001;98:1086910874.

27 Sorlie T, Tibshirani R, Parker J, Hastie T, Marron JS, Nobel A, et al: Repeated observation of breast tumor subtypes in independent gene expression data sets. Proc Natl Acad Sci USA 2003;100:8418-8423.

28 Rakha EA, Putti TC, Abd El-Rehim DM, Paish C, Green AR, Powe DG, et al: Morphological and immunophenotypic analysis of breast carcinomas with basal and myoepithelial differentiation. J Pathol 2006;208: 495-506.

29 Foulkes WD, Brunet JS, Stefansson IM, Straume O, Chappuis PO, Begin LR, et al: The prognostic implication of the basal-like (cyclin E high/p27 low/p53+/glomeruloidmicrovascular-proliferation+) phenotype of BRCA1-related breast cancer. Cancer Res 2004;64:830-835.

30 Langerod A, Zhao H, Borgan O, Nesland JM, Bukholm IR, Ikdahl T, et al: TP53 mutation status and gene expression profiles are powerful prognostic markers of breast cancer. Breast Cancer Res 2007;9:R30.

31 Charafe-Jauffret E, Ginestier C, Monville F, Finetti P, Adelaide J, Cervera N, et al: Gene expression profiling of breast cell lines identifies potential new basal markers. Oncogene 2006;25:2273-2284

32 Turner NC, Reis-Filho JS, Russell AM, Springall RJ, Ryder K, Steele D, et al: BRCA1 dysfunction in sporadic basal-like breast cancer. Oncogene 2007;26:2126-2132.

- 33 Foulkes WD, Stefansson IM, Chappuis PO, Begin LR, Goffin JR, Wong N, et al: Germline BRCA1 mutations and a basal epithelial phenotype in breast cancer. J Natl Cancer Inst 2003;95:1482-1485.
34 LakhaniSR, Reis-Filho JS, Fulford L, PenaultLlorca F, van der Vijver M, Parry S, et al: Prediction of BRCAl status in patients with breast cancer using estrogen receptor and basal phenotype. Clin Cancer Res 2005; 11: 5175-5180.

35 Turner NC, Reis-Filho JS: Basal-like breast cancer and the BRCA1 phenotype. Oncogene 2006;25:5846-5853.

- 36 Palacios J, Honrado E, Osorio A, Cazorla A, Sarrio D, Barroso A, et al: Immunohistochemical characteristics defined by tissue microarray of hereditary breast cancer not attributable to BRCA1 or BRCA 2 mutations: differences from breast carcinomas arising in BRCA1 and BRCA2 mutation carriers. Clin Cancer Res 2003;9:3606-3614

- 37 Arnes JB, Brunet JS, Stefansson I, Begin LR, Wong N, Chappuis PO, et al: Placental cadherin and the basal epithelial phenotype of BRCA1-related breast cancer. Clin Cancer Res 2005;11:4003-4011.

- 38 Lakhani SR, Van De Vijver MJ, Jacquemier J, Anderson TJ, Osin PP, McGuffog L, et al: The pathology of familial breast cancer: predictive value of immunohistochemical markers estrogen receptor, progesterone receptor, HER-2, and p53 in patients with mutations in BRCA1 and BRCA2. J Clin Oncol 2002;20:2310-2318.

39 Laakso M, Loman N, Borg A, Isola J: Cytokeratin 5/14-positive breast cancer: true basal phenotype confined to BRCA1 tumors. Mod Pathol 2005;18:1321-1328.

40 Turner N, Tutt A, Ashworth A: Hallmarks of 'BRCAness' in sporadic cancers. Nat Rev Cancer 2004;4:814-819.

-41 Tirkkonen M, Johannsson O, Agnarsson BA, Olsson H, Ingvarsson S, Karhu R, et al: Distinct somatic genetic changes associated with tumor progression in carriers of BRCA1 and BRCA2 germ-line mutations. Cancer Res 1997;57:1222-1227.

42 Jonsson G, Naylor TL, Vallon-Christersson J, Staaf J, Huang J, Ward MR, et al: Distinct genomic profiles in hereditary breast tumors identified by array-based comparative genomic hybridization. Cancer Res 2005;65: 7612-7621.

43 Wessels LF, van Welsem T, Hart AA, van’t Veer LJ, Reinders MJ, Nederlof PM: Molecular classification of breast carcinomas by comparative genomic hybridization: a specific somatic genetic profile for BRCA1 tumors. Cancer Res 2002;62:7110-7117.

44 Korsching E, Packeisen J, Agelopoulos K Eisenacher M, Voss R, Isola J, et al: Cytogenetic alterations and cytokeratin expression patterns in breast cancer: integrating a new model of breast differentiation into cytogenetic pathways of breast carcinogenesis. Lab Invest 2002;82:1525-1533. 
-45 Bergamaschi A, Kim YH, Wang P, Sorlie T, Hernandez-Boussard T, Lonning PE, et al: Distinct patterns of DNA copy number alteration are associated with different clinicopathological features and gene-expression subtypes of breast cancer. Genes Chromosomes Cancer 2006;45:1033-1040.

- 46 Jones C, Nonni AV, Fulford L, Merrett S, Chaggar R, Eusebi V, et al: CGH analysis of ductal carcinoma of the breast with basaloid/ myoepithelial cell differentiation. Br J Cancer 2001;85:422-427.

-47 Ganesan S, Silver DP, Greenberg RA, Avni D, Drapkin R, Miron A, et al: BRCA1 supports XIST RNA concentration on the inactive $\mathrm{X}$ chromosome. Cell 2002;111:393-405.

48 Richardson AL, Wang ZC, De Nicolo A, Lu X, Brown M, Miron A, et al: X chromosomal abnormalities in basal-like human breast cancer. Cancer Cell 2006;9:121-132.

-49 Paredes J, Milanezi F, Viegas L, Amendoeira I, Schmitt F: P-cadherin expression is associated with high-grade ductal carcinoma in situ of the breast. Virchows Arch 2002;440: $16-21$.

-50 Dabbs DJ, Chivukula M, Carter G, Bhargava $R$ : Basal phenotype of ductal carcinoma in situ: recognition and immunohistologic profile. Mod Pathol 2006;19:1506-1511.

- 51 Bryan BB, Schnitt SJ, Collins LC: Ductal carcinoma in situ with basal-like phenotype: a possible precursor to invasive basal-like breast cancer. Mod Pathol 2006;19:617-621.

52 Foulkes WD: BRCA1 functions as a breast stem cell regulator. J Med Genet 2004;41:15.

-53 Furuta S, Jiang X, Gu B, Cheng E, Chen PL, Lee WH: Depletion of BRCA1 impairs differentiation but enhances proliferation of mammary epithelial cells. Proc Natl Acad Sci USA 2005; 102:9176-9181.

54 Fan S, Wang J, Yuan R, Ma Y, Meng Q, Erdos $M R$, et al: BRCA1 inhibition of estrogen receptor signaling in transfected cells. Science 1999;284:1354-1356.

- 55 McCarthy A, Savage K, Gabriel A, Naceur C, Reis-Filho JS, Ashworth A: A mouse model of basal-like breast carcinoma with metaplastic elements. J Pathol 2007;211:389-398.

- 56 Livasy CA, Karaca G, Nanda R, Tretiakova MS, Olopade OI, Moore DT, et al: Phenotypic evaluation of the basal-like subtype of invasive breast carcinoma. Mod Pathol 2006; 19:264-271.

57 Fulford LG, Easton DF, Reis-Filho JS, Sofronis A, Gillett CE, Lakhani SR, et al: Specific morphological features predictive for the basal phenotype in grade 3 invasive ductal carcinoma of breast. Histopathology 2006; 49:22-34.

58 Nielsen TO, Hsu FD, Jensen K, Cheang M, Karaca G, Hu Z, et al: Immunohistochemical and clinical characterization of the basallike subtype of invasive breast carcinoma. Clin Cancer Res 2004;10:5367-5374.
Rodriguez-Pinilla SM, Sarrio D, Honrado E, Moreno-Bueno G, Hardisson D, Calero F, et al: Vimentin and laminin expression is associated with basal-like phenotype in both sporadic and BRCA1-associated breast carcinomas. J Clin Pathol 2007;60:1006-1012.

60 Carey LA, Perou CM, Livasy CA, Dressler LG, Cowan D, Conway K, et al: Race, breast cancer subtypes, and survival in the Carolina Breast Cancer Study. JAMA 2006;295: 2492-2502.

61 Livasy CA, Perou CM, Karaca G, Cowan DW, Maia D, Jackson S, et al: Identification of a basal-like subtype of breast ductal carcinoma in situ. Hum Pathol 2007;38:197-204.

62 Rodriguez-Pinilla SM, Sarrio D, MorenoBueno G, Rodriguez-Gil Y, Martinez MA, Hernandez L, et al: Sox2: a possible driver of the basal-like phenotype in sporadic breast cancer. Mod Pathol 2007;20:474-481.

63 Rodriguez-Pinilla SM, Rodriguez-Gil Y, Moreno-Bueno G, Sarrio D, Martin-Guijarro MD, Hernandez L, et al: Sporadic invasive breast carcinomas with medullary features display a basal-like phenotype: an immunohistochemical and gene amplification study. Am J Surg Pathol 2007;31:501-508.

64 Pinilla SM, Honrado E, Hardisson D, Benitez J, Palacios J: Caveolin-1 expression is associated with a basal-like phenotype in sporadic and hereditary breast cancer. Breast Cancer Res Treat 2006;99:85-90.

65 Rakha EA, El-Sayed ME, Green AR, Paish EC, Lee AH, Ellis IO: Breast carcinoma with basal differentiation: a proposal for pathology definition based on basal cytokeratin expression. Histopathology 2007;50:434-438.

66 Banerjee S, Reis-Filho JS, Ashley S, Steele D, Ashworth A, Lakhani SR, et al: Basal-like breast carcinomas: clinical outcome and response to chemotherapy. J Clin Pathol 2006; 59:729-735.

67 Fulford LG, Reis-Filho JS, Ryder K, Jones C, Gillett CE, Hanby A, et al: Basal-like grade III invasive ductal carcinoma of the breast: patterns of metastasis and long-term survival. Breast Cancer Res 2007;9:R4.

-68 Jones C, Ford E, Gillett C, Ryder K, Merrett S, Reis-Filho JS, et al: Molecular cytogenetic identification of subgroups of grade III invasive ductal breast carcinomas with different clinical outcomes. Clin Cancer Res 2004;10: 5988-5997.

69 Potemski P, Kusinska R, Watala C, Pluciennik E, Bednarek AK, Kordek R: Prognostic relevance of basal cytokeratin expression in operable breast cancer. Oncology 2005;69: 478-485.

70 Rakha EA, El-Rehim DA, Paish C, Green AR, Lee AH, Robertson JF, et al: Basal phenotype identifies a poor prognostic subgroup of breast cancer of clinical importance. Eur J Cancer 2006;42:3149-3156.

71 Fan C, Oh DS, Wessels L, Weigelt B, Nuyten DS, Nobel AB, et al: Concordance among gene-expression-based predictors for breast cancer. N Engl J Med 2006;355:560-569.
72 Rouzier R, Perou CM, Symmans WF, Ibrahim N, Cristofanilli M, Anderson K, et al: Breast cancer molecular subtypes respond differently to preoperative chemotherapy. Clin Cancer Res 2005;11:5678-5685.

-73 Calza S, Hall P, Auer G, Bjohle J, Klaar S, Kronenwett $\mathrm{U}$, et al: Intrinsic molecular signature of breast cancer in a population-based cohort of 412 patients. Breast Cancer Res 2006;8:R34.

-74 Tischkowitz M, Brunet JS, Begin LR, Huntsman DG, Cheang MC, Akslen LA, et al: Use of immunohistochemical markers can refine prognosis in triple negative breast cancer. BMC Cancer 2007;7:134.

75 Rody A, Karn T, Solbach C, Gaetje R, Munnes M, Kissler S, et al: The erbB2+ cluster of the intrinsic gene set predicts tumor response of breast cancer patients receiving neoadjuvant chemotherapy with docetaxel, doxorubicin and cyclophosphamide within the GEPARTRIO trial. Breast 2007; 16:235-240.

76 Rakha EA, El-Sayed ME, Green AR, Lee AH, Robertson JF, Ellis IO: Prognostic markers in triple-negative breast cancer. Cancer 2007; 109:25-32.

-77 Abd El-Rehim DM, Pinder SE, Paish CE, Bell J, Blamey RW, Robertson JF, et al: Expression of luminal and basal cytokeratins in human breast carcinoma. J Pathol 2004;203:661671.

78 Reis-Filho JS, Milanezi F, Steele D, Savage K, Simpson PT, Nesland JM, et al: Metaplastic breast carcinomas are basal-like tumours. Histopathology 2006;49:10-21.

79 Jacquemier J, Padovani L, Rabayrol L, Lakhani SR, Penault-Llorca F, Denoux Y, et al: Typical medullary breast carcinomas have a basal/myoepithelial phenotype. J Pathol 2005;207:260-268.

80 Tsuda H, Takarabe T, Hasegawa F, Fukutomi T, Hirohashi S: Large, central acellular zones indicating myoepithelial tumor differentiation in high-grade invasive ductal carcinomas as markers of predisposition to lung and brain metastases. Am J Surg Pathol 2000;24: 197-202.

81 Diallo-Danebrock R, Ting E, Gluz O, Herr A, Mohrmann S, Geddert H, et al: Protein expression profiling in high-risk breast cancer patients treated with high-dose or conventional dose-dense chemotherapy. Clin Cancer Res 2007;13:488-497.

82 Seewaldt VL, Scott V: Images in clinical medicine. Rapid progression of basal-type breast cancer. N Engl J Med 2007;356:e12.

83 Collett K, Stefansson IM, Eide J, Braaten A, Wang H, Eide GE, et al: A basal epithelial phenotype is more frequent in interval breast cancers compared with screen detected tumors. Cancer Epidemiol Biomarkers Prev 2005; 14:1108-1112. 
-84 van de Rijn M, Perou CM, Tibshirani R, Haas $\mathrm{P}$, Kallioniemi O, Kononen J, et al: Expression of cytokeratins 17 and 5 identifies a group of breast carcinomas with poor clinical outcome. Am J Pathol 2002;161:19911996.

-85 Gaedcke J, Traub F, Milde S, Wilkens L, Stan A, Ostertag $\mathrm{H}$, et al: Predominance of the basal type and HER-2/neu type in brain metastasis from breast cancer. Mod Pathol 2007; 20:864-870.

-86 Patanaphan V, Salazar OM, Risco R: Breast cancer: metastatic patterns and their prognosis. South Med J 1988;81:1109-1112.

-87 Rodriguez-Pinilla SM, Sarrio D, Honrado E, Hardisson D, Calero F, Benitez J, et al: Prognostic significance of basal-like phenotype and fascin expression in node-negative invasive breast carcinomas. Clin Cancer Res 2006;12:1533-1539.

-88 Hicks DG, Short SM, Prescott NL, Tarr SM, Coleman KA, Yoder BJ, et al: Breast cancers with brain metastases are more likely to be estrogen receptor negative, express the basal cytokeratin CK5/6, and overexpress HER2 or EGFR. Am J Surg Pathol 2006;30:10971104.

89 Bocker W, Moll R, Poremba C, Holland R, Van Diest PJ, Dervan P, et al: Common adult stem cells in the human breast give rise to glandular and myoepithelial cell lineages: a new cell biological concept. Lab Invest 2002; 82:737-746.

$\checkmark 90$ Haffty BG, Yang Q, Reiss M, Kearney T, Higgins SA, Weidhaas J, et al: Locoregional relapse and distant metastasis in conservatively managed triple negative early-stage breast cancer. J Clin Oncol 2006;24:5652-5657.

91 Tan DS, Marchió C, Jones RL, Savage K, Smith IE, Dowsett M, et al: Triple negative breast cancer: molecular profiling and prognostic impact in adjuvant anthracyclinetreated patients. Breast Cancer Res Treat, in press.

92 Kusinska R, Potemski P, Jesionek-Kupnicka D, Kordek R: Immunohistochemical identification of basal-type cytokeratins in invasive ductal breast carcinoma - relation with grade, stage, estrogen receptor and HER2. Pol J Pathol 2005;56:107-110.
$\$ 93$ Guarneri V, Broglio K, Kau SW, Cristofanilli M, Buzdar AU, Valero V, et al: Prognostic value of pathologic complete response after primary chemotherapy in relation to hormone receptor status and other factors. J Clin Oncol 2006;24:10371044.

94 Urruticoechea A, Smith IE, Dowsett M: Proliferation marker Ki-67 in early breast cancer. J Clin Oncol 2005;23:7212-7220.

$\checkmark 95$ Carey LA, Dees EC, Sawyer L, Gatti L, Moore DT, Collichio F, et al: The triple negative paradox: primary tumor chemosensitivity of breast cancer subtypes. Clin Cancer Res 2007;13:2329-2334.

-96 Geisler S, Lonning PE, Aas T, Johnsen H, Fluge $\mathrm{O}$, Haugen DF, et al: Influence of TP53 gene alterations and c-erbB-2 expression on the response to treatment with doxorubicin in locally advanced breast cancer. Cancer Res 2001;61:2505-2512.

97 Lanni JS, Lowe SW, Licitra EJ, Liu JO, Jacks T: p53-independent apoptosis induced by paclitaxel through an indirect mechanism. Proc Natl Acad Sci USA 1997;94:96799683.

98 Kandioler-Eckersberger D, Ludwig C, Rudas M, Kappel S, Janschek E, Wenzel C, et al: TP53 mutation and p53 overexpression for prediction of response to neoadjuvant treatment in breast cancer patients. Clin Cancer Res 2000;6:50-56.

\$9 Chappuis PO, Goffin J, Wong N, Perret C, Ghadirian P, Tonin PN, et al: A significant response to neoadjuvant chemotherapy in BRCA1/2 related breast cancer. J Med Genet 2002;39:608-610.

100 Robson ME, Chappuis PO, Satagopan J, Wong N, Boyd J, Goffin JR, et al: A combined analysis of outcome following breast cancer: differences in survival based on BRCA1/BRCA2 mutation status and administration of adjuvant treatment. Breast Cancer Res 2004;6:R8-R17.

101 Farmer H, McCabe N, Lord CJ, Tutt AN, Johnson DA, Richardson TB, et al: Targeting the DNA repair defect in BRCA mutant cells as a therapeutic strategy. Nature 2005; 434:917-921.

102 Kennedy RD, Quinn JE, Mullan PB, Johnston PG, Harkin DP: The role of BRCA1 in the cellular response to chemotherapy. J Natl Cancer Inst 2004;96:1659-1668.

103 Turner N, Tutt A, Ashworth A: Targeting the DNA repair defect of BRCA tumours. Curr Opin Pharmacol 2005;5:388-393.
04 De Soto JA, Deng CX: PARP-1 inhibitors: are they the long-sought genetically specific drugs for BRCA1/2-associated breast cancers? Int J Med Sci 2006;3:117-123.

105 Adjei AA, Hidalgo M: Treating cancer by blocking cell signals. J Clin Oncol 2005;23: 5279-5280.

106 Kim MJ, Ro JY, Ahn SH, Kim HH, Kim SB, Gong G: Clinicopathologic significance of the basal-like subtype of breast cancer: a comparison with hormone receptor and Her2/neu-overexpressing phenotypes. Hum Pathol 2006;37:1217-1226.

107 Simon R, Panussis S, Maurer R, Spichtin H, Glatz K, Tapia C, et al: KIT (CD117)-positive breast cancers are infrequent and lack KIT gene mutations. Clin Cancer Res 2004; 10:178-183.

108 Finn RS, Dering J, Ginther C, Wilson CA, Glaspy P, Tchekmedyian N, et al: Dasatinib, an orally active small molecule inhibitor of both the src and abl kinases, selectively inhibits growth of basal-type/'triple-negative' breast cancer cell lines growing in vitro. Breast Cancer Res Treat 2007;105: 319-326.

109 Huang F, Reeves K, Han X, Fairchild C, Platero S, Wong TW, et al: Identification of candidate molecular markers predicting sensitivity in solid tumors to dasatinib: rationale for patient selection. Cancer Res 2007;67:2226-2238.

110 Reis-Filho JS, Pinheiro C, Lambros MB, Milanezi F, Carvalho S, Savage K, et al: EGFR amplification and lack of activating mutations in metaplastic breast carcinomas. J Pathol 2006;209:445-453.

111 Mendelsohn J: Targeting the epidermal growth factor receptor for cancer therapy. J Clin Oncol 2002;20:1S-13S.

112 Mendelsohn J, Baselga J: Epidermal growth factor receptor targeting in cancer. Semin Oncol 2006;33:369-385.

113 Burris HA 3rd, Hurwitz HI, Dees EC, Dowlati A, Blackwell KL, O’Neil B, et al: Phase I safety, pharmacokinetics, and clinical activity study of lapatinib (GW572016), a reversible dual inhibitor of epidermal growth factor receptor tyrosine kinases, in heavily pretreated patients with metastatic carcinomas. J Clin Oncol 2005;23:5305-5313. 